\title{
APLIKASI LIMBAH CAIR PABRIK KELAPA SAWIT DAN NPK ORGANIK PADA TANAMAN TIMUN SURI (Cucumis sativus L.)
}

\author{
Application of Palm Oil Mill Liquid Waste and Organic NPK \\ in Cucumber Suri Plants (Cucumis Sativus L.)
}

Daniel, Siti Zahrahdan Fathurrahman

Fakultas Pertanian Universitas Islam Riau, Jl. Kaharuddin Nasution 113, Pekanbaru 28284 Riau Telp:0761-72126 ext. 123, fax: 0761-674681

[Diterima: Oktober 2017; Disetujui: Desember 2017]

\begin{abstract}
The study aimed to determine the effect of interaction between palm oil mill and organic NPK liquid waste doses on the growth and production of Suri Cucumber plants. The design used in this study was a Factorial Completely Randomized Design consisting of 2 factors. The first factor is palm oil mill effluent with a dose of $0,100,200,300 \mathrm{ml} /$ plant while the second factor is organic NPK with a dose of $0,5,10,15$ grams/plant. The parameters observed were flowering age, age of the first harvest, number of fruit crops, the weight of fruit per fruit, weight of fruit per plant. The last observation data were analyzed statistically and continued with a BNJ follow-up test at the level of $5 \%$. The results showed that interactively the administration of palm oil mill effluent and organic NPK fertilizer gave a significant effect on fruit weight per fruit and fruit weight per Suri cucumber plant. The best treatment is a combination of $300 \mathrm{ml} / \mathrm{plant}$ palm oil mill effluent and $15 \mathrm{~g} /$ plant organic NPK fertilizer (L3N3). The main effect of giving palm oil mill effluent has a significant effect on flowering age, harvest age, number of fruits per plant, fruit weight per fruit and fruit weight per Suri cucumber plant. The best treatment is by giving $300 \mathrm{ml} /$ plant palm oil mill effluent (L3). The main effect of giving organic NPK fertilizer significantly affected flowering age, harvest age, number of fruits per plant, fruit weight per fruit and fruit weight per Suri cucumber plant. The best treatment is by administering $15 \mathrm{~g}$ of organic NPK / plant (N3).
\end{abstract}

Keywords: Cucumber Suri, LCPKS, NPK

\begin{abstract}
ABSTRAK
Tujuan penelitian untuk mengetahui pengaruh interaksi dosis limbah cair pabrik kelapa sawit dan NPK organik terhadap pertumbuhan dan produksi tanaman Mentimun Suri. Rancangan yang digunakan dalam penelitian ini adalah Rancangan Acak Lengkap Faktorial yang terdiri dari 2 faktor. Faktor pertama adalah limbah cair pabrik kelapa sawit dengan dosis 0, 100, 200, $300 \mathrm{ml} / \mathrm{tanaman}$ sedangkan faktor kedua yaitu NPK organik dengan dosis $0,5,10,15$ gram/tanaman. Parameter yang diamati adalah umur berbunga, umur panen pertama, jumlah buah pertanaman, berat buah per buah, berat buah per tanaman. Data pengamatan terakhir dianalisis secara statistik dan dilanjutkan dengan uji lanjut BNJ pada taraf 5\%. Hasil penelitian menunjukan bahwa secara interaksi pemberian limbah cair pabrik kelapa sawit dan pupuk NPK organik memberikan pengaruh nyata terhadap berat buah per buah dan berat buah per tanaman tanaman timun suri. Perlakuan terbaik adalah kombinasi limbah cair pabrik kelapa sawit $300 \mathrm{ml} / \operatorname{tanaman}$ dan pupuk NPK organik $15 \mathrm{~g} / \operatorname{tanaman}\left(\mathrm{L}_{3} \mathrm{~N}_{3}\right)$. Pengaruh utama pemberian limbah cair pabrik kelapa sawit berpengaruh nyata terhadap umur berbunga, umur panen, jumlah buah per tanaman, berat buah per buah dan berat buah per tanaman tanaman timun suri. Perlakuan terbaik adalah dengan pemberian limbah cair pabrik kelapa sawit $300 \mathrm{ml} / \mathrm{tanaman}$ $\left(\mathrm{L}_{3}\right)$. Pengaruh utama pemberian pupuk NPK organik berpengaruh nyata terhadap umur berbunga, umur panen, jumlah buah per tanaman, berat buah per buah dan berat buah per tanaman tanaman timun suri. Perlakuan terbaik adalah dengan pemberian pupuk NPK organik $15 \mathrm{~g} / \operatorname{tanaman}\left(\mathrm{N}_{3}\right)$.
\end{abstract}

Kata Kunci: Timun Suri, LCPKS, NPK 


\section{PENDAHULUAN}

Timun suri (Cucumis sativus L.) merupakan tanaman semusim dari kelompok tanaman holtikultura keluarga labu-labuan (Cucurbitaceae) yang dapat dimakan baik dalam kondisi segar ataupun diolah lebih lanjut. Selain untuk bahan makanan, timun suri juga banyak digunakan sebagai bahan baku pada industri kecantikan. Manfaat lainnya yang diperoleh dari buah timun suri adalah biji timun suri yang memiliki racun alkaloid jenis hipoxanti untuk mengobati anak-anak yang menderita cacingan, penyakit disentri, menurunkan darah tinggi (hipertensi) dan mencegah keracunan saat kehamilan.

Sebagai sayuran buah timun suri kaya akan sumber vitamin dan mineral yang dibutuhkan oleh tubuh.

Direktorat gizi Depkes RI (1981) dalam Rismunandar (1993) menyebutkan kandungan gizi dalam 100 gram buah segar timun suri adalah sebagai berikut : kalori $12,00 \mathrm{k}$, protein $0,60 \mathrm{~g}$, lemak 0,02 mg, kalium 122,00 mg, zat besi $0,04 \mathrm{mg}$, natrium $5,00 \mathrm{mg}$, vitamin BI 0.02 $\mathrm{mg}$, vitaminB2 $0,02 \mathrm{mg}$ niacin $0,01 \mathrm{mg}$, vitamin C 10,00 mg, Air 96,00 g.

Melalui angka produksi timun, diketahui bahwa telah terjadi penurunan hasil produksi tanaman timun di Indonesia dalam beberapa tahun belakangan ini. Data tahun 2013 menyatakan bahwa total produksi timun di seluruh wilayah Indonesia mencapai 491.636 ton. Pada tahun 2014 turun menjadi 477.989 ton dan di tahun 2015 turun kembali menjadi 447.696 ton. Sementara itu, di Provinsi Riau sendiri juga tejadi penurunan produksi timun yang sangat memprihatinkan. Tahun 2013 produksi timun di Riau mencapai 20.727 ton. Tahun 2014 turun menjadi 19.331 ton dan di tahun 2015 turun menjadi 14.175 ton (BPS, 2016)

Permasalahan utama yang dihadapi petani di Indonesia umumnya kurang memperhatikan pemupukan organik pada budidaya tanaman, petani cenderung menggunakan pupuk kimia (anorganik) untuk memenuhi kebutuhan unsur hara pada tanaman budidaya tanpa memperhatikan kebutuhan yang dikehendaki oleh tanaman tersebut sehingga produksi pada tanaman budidaya kurang optimal dan kesuburan tanah menurun. Pupuk organik dapat menggantikan unsur hara yang dibutuhkan tanaman pada pupuk anorganik, juga dapat melestarikan lingkungan (Ingsan, 2015).

Pupuk yang diberikan kepada tanaman berdasarkan sifatnya ada dua macam, yaitu pupuk organik dan pupuk dan anorganik. Penggunaan pupuk anorganik secara terus menerus dan berlebihan dapat menurunkan kesuburan tanah dan merusak lingkungan serta kesehatan, sehingga penggunaan pupuk anorganik perlu dikurangi dengan mengalihkan penggunaan pupuk organik (Fadli, 2014).

Pertanian organik merupakan solusi untuk mengatasi dampak negatif akibat penggunaan bahan-bahan anorganik yang terkandung didalam pupuk dan pestisida. Pertanian organik adalah suatu kegiatan bercocok tanam yang akrab dengan lingkungan dan meminimalkan dampak negatif bagi alam sekitar dan memaksimalkan dampak positif bagi perbaikan struktur dan porositas tanah.

Selama ini bahan organik yang dipergunakan dalam budidaya tanaman terfokus pada pupuk kandang saja, namun dari waktu kewaktu ketersediaan pupuk kandang semakin sulit diperoleh karena pemakaian yang sangat luas dan harga yang semakin mahal. Untuk itu perlu dicari alternatif lain sebagai pengganti pupuk kandang tersebut, salah satunya adalah dengan menggunakan limbah cair olahan kelapa sawit.

Limbah cair yang dapat dimanfaatkan sebagai penambahan kesuburan tanah yang termasuk pupuk organik. Jika ini tidak dikelola dengan baik maka akan mencemari lingkungan berupa bau yang tidak sedap akibat adanya dekomposisi kandungan solid oleh mikroorganisme. Oleh karena itu perlu adanya perhatian yang sungguh-sunguh agar limbah yang berpotensi sebagai pencemaran lingkungan dapat berubah menjadi sumber daya alam yangpotensial dan ramah lingkungan untuk kegiatan budidaya tanaman. Limbah cair olahan pabrik kelapa sawit sangat potensial dikembangkan karena banyak memberikan keuntungan diantaranya tersedia dalam jumlah melimpah, memiliki kandungan unsur hara yang cukup tinggi, mampu memperbaiki sifat fisik, kimia, dan biologi tanah. Selain itu, limbah cair kelapa sawit harganya relatif murah serta mudah dalam pengaplikasian dilapangan 
seperti penggunaan pupuk organik lainnya (Betty, 2007).

Tujuan penelitian untuk mengetahui pengaruh secara interaksi dan tunggal dosis limbah cair pabrik kelapa sawit dan NPK organik terhadap pertumbuhan dan produksi tanaman Mentimun Suri.

\section{BAHAN DAN METODE}

Penelitian ini telah dilaksanakan di Kebun Percobaan Fakultas PertanianUniversitas Islam Riau. Pelaksanaan penelitian selama 4 bulan terhitung dari Bulan Juni sampai September 2017.

Bahan-bahan yang digunakan dalam penelitian ini adalah benih timun suri varietas lokal. limbah cair pabrik kelapa sawit, NPK organik,plastik sungkup buah,Dithane M45,Regent, Furadan 3GR,seng plat,spanduk penelitian, tali rafia dan cat. Limbah cair CPO kelapa sawit diambilpada kolam ke 4 (anaerob primer) perkebunan kelapa sawit PTPN V Seigaro, Kecamatan Tapung Kabupaten Kampar

Alat-alat yang digunakan dalam
penelitian ini ember,gembor,meteran, timbangan analitik, timbangan jarum,palu,handsprayer, gelas ukur, paku, parang, kamera, masker, sarung tangan lateks, jerigendan alat tulis.

Penelitian ini menggunakan Rancangan Acak Lengkap (RAL) Faktorial yang terdiri dari 2 faktor,dimana faktor pertama yaitu AplikasiLimbah cair CPO kelapa sawit (L)yang terdiri dari 4 taraf dan faktor yang kedua yaitu pemberian pupuk NPK Organik $(\mathrm{N})$ yang terdiri dari 4 taraf sehingga didapat 16 kombinasi perlakuan.Setiap kombinasi perlakuan tersebut diulang sebanyak 3 kali sehingga total keseluruhan 48 satuan percobaan. Setiap satuan percobaan(plot) terdiri dari 4 tanaman dan 2 tanaman digunakan sebagai sampel,sehingga total keseluruhan tanaman berjumlah 192 tanaman.

Adapun faktor perlakuannya adalah :Faktor L (Pemberian Limbah cair pabrik kelapa sawit) yaitu $: \mathrm{L}_{0}=$ Tanpa limbah cair pabrik kelapa sawit, $\mathrm{L}_{1}=$ Limbah cair pabrik kelapa sawit100 ml/tanaman, $\mathrm{L}_{2}=$ Limbah cair pabrik kelapa sawit $200 \mathrm{ml} /$ tanaman, $\mathrm{L}_{3}=$ Limbah cair pabrik kelapa sawit 300 ml/tanaman, Faktor N (Pemberian NPK Organik) yaitu $: \mathrm{N}_{0}=$ TanpaNPK Organik, $\mathrm{N}_{1}$ $=\mathrm{NPK}$ organik 5 gram/tanaman $(200 \mathrm{~kg} / \mathrm{Ha}), \mathrm{N}_{2}$ = NPK organik 10 gram/tanaman $(400 \mathrm{~kg} / \mathrm{Ha})$, $\mathrm{N}_{3}=$ NPK organik 15 gram/tanaman (600 $\mathrm{kg} / \mathrm{Ha})$.

Data hasil pengamatan dari masingmasing perlakuan kemudian dianalisis secara statistik,apabila $\mathrm{F}$ hitung lebih besar dari $\mathrm{F}$ tabel maka dilanjutkan dengan uji lanjut BNJ (Beda Nyata Jujur) pada taraf 5\%.

Limbah cair pabrik kelapa sawit yang digunakan diambilpada kolam ke 4 (anaerob primer) perkebunan kelapa sawit PTPN V Seigaro, Kecamatan Tapung Kabupaten Kampar. Pemberian limbah cair pabrik kelapa sawit dilakukan dua kali masing-masing setengah dosis dari masing-masing taraf perlakuan yang diberikan pada saat 1 minggu sebelum tanam dan 2 minggu setelah tanam. Sebelum penyiraman, terlebih dahulu dilakukan pengukuran jarak tanam guna menentukan posisi tanaman. Kemudian posisi hasil pengukuran ditandai dengan penancapan lidi agar mempermudah aplikasi limbah cair pabrik kelapa sawit. Aplikasi limbah dilakukan dengan cara menyiramkan larutan limbah cair pabrik kelapa sawit dengan jarak $10 \mathrm{~cm}$ mengelilingi lidi (sebelum tanam) dan pangkal batang tanaman (setelah tanam). Aplikasi limbah cair pabrik kelapa sawit dengan dosis sesuai perlakuan, yakni $0, \quad 100,200$ dan300 ml/tanaman.

Pupuk NPK organik yang digunakan berasal dari toko Cahaya Tani Jalan Agus Salim, Pekanbaru.Pemberian NPK organik dilakukan 1 kali pada waktu penanaman. Pemberian pupuk NPK organik ini dilakukan dengan melingkaryang berjarak $10 \mathrm{~cm}$ dari lidi (penanda lubang tanam). Pemberian NPK organiksesuaidengandosis, yakni $0,5,10,15$ g/tanaman.

Parameter yang diamati adalah umur berbunga (Hst), umur panen pertama (Hst), jumlah buah per tanaman (buah), berat buah per buah $(\mathrm{kg})$, berat buah per tanaman $(\mathrm{kg})$.

\section{HASIL DAN PEMBAHASAN}

\section{Umur Berbunga (HST)}

Data pada Tabel 1 menunjukan bahwa pengaruh utama pemberian limbah cair pabrik 
kelapa sawit memberikan pengaruh yang nyata terhadap parameter umur berbunga timun suri dimana umur berbunga tercepat terdapat pada pemberian limbah cair pabrik kelapa sawit 300 $\mathrm{ml}\left(\mathrm{L}_{3}\right)$ yaitu 26,83 hari setelah tanam yang tidak berbeda nyata dengan dengan perlakuan $\mathrm{L}_{2}$, namun berbeda nyata dengan $\mathrm{L}_{1}$ dan $\mathrm{L}_{0}$.

Cepatnya umur berbunga tanaman suri pada perlakuan $\mathrm{L}_{3}$ diduga karena telah terpenuhinya kebutuhan unsur hara dalam tumbuh kembang dan produksi. Limbah cair pabrik kelapa sawit juga mengandung unsur hara yang dibutuhkan oleh tanaman seperti N, P dan K. Selain itu secara fisik limbah cair kelapa sawit memiliki fungsi membentuk agregat tanah yang berpengaruh besar terhadap porositas dan aerasi dan drainase persediaan air dalam tanah. Hal ini menyebabkan akar tumbuh dan bekembang dengan maksimal sehingga penyerapan hara dan air maksimal. Secara kimia berperan penyerapan racun bagi tanaman seperti alumunium (Al), besi (Fe), dan mangan $(\mathrm{Mn})$, Secara biologi pemberian limbah cair kelapa sawit dapat meningkatkan mikroorganisme di dalam tanah yang menyebabkan peningkatan penguraian bahan organik tanah serta dapat meningkatkan $\mathrm{PH}$ tanah dan meningkatkan kapasitas tukar kation dan anion tanah (KTK dan KTA), sehingga unsur hara tersedia bagi tanaman dengan baik dan seimbang. (Lubis dan Tobing, 2011).

Suatu tanaman akan tumbuh dengan baik dan subur jika semua unsur hara yang dibutuhkan tanaman yang dapat menyebabkan tanaman menjadi kerdil, daun pucat yang disebabkan oleh terhambatnya proses pembelahan dan pembesarann sel tanaman. Kekurangan unsur $\mathrm{P}$ akan memperlambat proses fisiologis, seperti proses fotosintesis dan respirasi pada tanaman. Kekurangan unsur $\mathrm{K}$ akan menghambat produksi (Lakitan dan Benyamin, 2007).

Hasil penelitian Mas'ud (2013) juga menjelaskan bahwa pemberian dosis pupuk yang sesuai serta kebutuhan unsur hara yang terpenuhi dapat mempercepat umur berbunga tanaman. Kebutuhan unsur hara merupakan faktor penting bagi tanaman dalam tumbuh, kembang, serta produksi, adapan perubahan yang terjadi, walaupun dalam kondisi kecil akan berpengaruh besar terhadap tanaman. Sementara itu, pada penelitian yang dilakukan oleh Irawan (2015) menyatakan pemberian limbah cair pabrik kelapa sawit mampu mempercepat umur berbunga tanaman cabai merah mencapai 10 hari lebih cepat dibandingkan dengan deskripsi tanaman cabai merah.

Selain itu, data pada Tabel 1 juga menunjukan bahwa secara utama pemberian NPK organik memberikan pengaruh yang nyata terhadap parameter umur berbunga timun suri, dimana umur berbunga tercepat terdapat pada pemberian NPK organik dengan dosis 15 g/tanaman $\left(\mathrm{N}_{3}\right)$ yaitu 27 hari setelah tanam yang tidak berbeda nyata dengan dengan perlakuan $\mathrm{N}_{2}$, namun berbeda nyata dengan $\mathrm{N}_{1}$ dan $\mathrm{N}_{0}$.

Berdasarkan umur berbunga timun suri pada deskripsi dan hasil penelitian sebelumnya. Umur berbunga timun suri telah mampu mencapai umur berbunga sesuai deskripsi.Hasil penelitian Fadli (2013) tentang pengaruh berbagai jenis pupuk organik dan NPK organik terhadap pertumbuhan dan hasil tanaman timun suri, umur berbunga tercepat yang yang mampu dicapai yaitu 32,92 HST dengan perlakuan pupuk organik jenis bokashi. Sedangkan Syarif (2017) pada perlakuan pupuk Bio Organik Plus dan Urea mampu berbunga pada umur, 22,08 HST.

Tabel 1. Rerata umur berbunga timun suri perlakuan limbah cair pabrik kelapa sawit dan NPK organik (HST).

\begin{tabular}{|c|c|c|c|c|c|}
\hline \multirow{2}{*}{$\begin{array}{c}\text { Limbah } \\
(\mathrm{ml})\end{array}$} & \multicolumn{4}{|c|}{ NPK Organik (g) } & \multirow{2}{*}{ Rerata } \\
\hline & $\mathrm{N}_{0}(0)$ & $\mathrm{N}_{1}(5)$ & $\mathrm{N}_{2}(10)$ & $\mathrm{N}_{3}(15)$ & \\
\hline $\mathrm{L}_{0}(0)$ & 30,00 & 28,67 & 28,00 & 28,00 & $28,67 \mathrm{~b}$ \\
\hline $\mathrm{L}_{1}(100)$ & 29,00 & 28,67 & 28,00 & 27,67 & $28,33 \mathrm{~b}$ \\
\hline $\mathrm{L}_{2}(200)$ & 29,33 & 28,67 & 26,67 & 26,33 & $27,75 \mathrm{ab}$ \\
\hline $\mathrm{L}_{3}(300)$ & 27,33 & 27,33 & 26,67 & 26,00 & $26,83 \mathrm{a}$ \\
\hline Rerata & $28,92 \mathrm{c}$ & $28,33 \mathrm{bc}$ & $27,33 \mathrm{ab}$ & $27,00 \mathrm{a}$ & \\
\hline
\end{tabular}

$\mathrm{KK}=4,14 \%$ BNJ L \&N $=1.28$

Angka-angka pada baris dan kolom yang diikuti huruf kecil yang sama menunjukkan tidak berbeda nyata menurut uji lanjut Beda Nyata Jujur pada taraf $5 \%$ 
Pearce dan Mitchell (1991) dalamBertua et al., (2012), menyatakan bahwa ada dua faktor yang mempengaruhi kecepatan berbunga pada tanaman yaitu faktor eksternal dan internal (lingkungan) seperti cahaya matahari dan ketersediaan unsur hara cahaya dapat meningkatkan pengangkutan unsur hara

dengan memasok produk-produk dari foto sintesis yang merangsang pembentukan bunga, penyinaran juga dapat menyebabkan membuka dan menutup bunga. faktor internal (genetik) tanaman itu sendiri yaitu apabila umur tanaman sudah melewati masa vegetatif maka tanaman akan berbunga.

Secara umum keuntungan yang diperoleh dengan menggunakan pupuk organik yamg pertama adalah bahan organik akan mempengaruhi sifat fisik tanah. Warna tanah yang semula cerah akan berubah menjadi kelam setelah pemberian bahan organik. Tanah menjadi gembur dan akar akan lebih mudah melakukan penetrasi, sehingga pertumbuhan akar akan menjadi lebih baik dan selanjutnya akan memberikan dampak positif terhadap pertumbuhan tanaman. Keuntunga berikutnya adalah penambahan bahan organik akan memperbaiki sifat biologi tanah. Bahan organik menambah energi yang diperlukan kehidupan mikroorganisme tanah. Tingginya bahan organik yang diberikan ketanah akan mempercepat memperbanyak fungi, bakteri, mikro, flora dan mikro fauna tanah yang dibutuhkan tanaman (Sutanto,2002).

Adanya perbedaan waktu umur berbunga dalam proses pembungaan tanaman timun suri diduga karena perbedaan dosis pupuk, baik itu limbah cair pabrik kelapa sawit maupun pupuk NPK organik yang diberikan sebagaimana yang kita ketehui, pemberian unsur hara yang terlalui berlebihan maupun terlalu sedikit akan berpengaruh buruk untuk pertumbuhan dan perkembangan tanaman. Hal ini sesuai dengan pendapat Basir et al., (2003).

\section{Umur Panen (HST)}

Data pada Tabel 2 menunjukan bahwa secara utama pemberian limbah cair pabrik kelapa sawit berpengaruh nyata terhadap parameter umur panen tanaman timun suri, dimana umur panen tercepat terdapat pada pemberian limbah cair pabrik kelapa sawit $\left(\mathrm{L}_{3}\right)$ yaitu 63,92 hari setelah tanam, tidak berbeda nyata dengan $\left(\mathrm{L}_{2}\right)$ yaitu 65,58 akan tetapi berbeda nyata dengan pemberian limbah cair pabrik kelapa sawit $\left(\mathrm{L}_{1}\right)$ yaitu66,83 hari setelah tanam dan umur panen paling lama terdapat pada tanpa pemberian limbah cair pabrik kelapa sawit $\left(\mathrm{L}_{0}\right)$ yaitu, 67,33 hari setelah tanam.

Tabel 2. Rerata umur panen timun suri perlakuan limbah cair pabrik kelapa sawit dan NPK organik (HST).

\begin{tabular}{|c|c|c|c|c|c|}
\hline \multirow{2}{*}{$\begin{array}{c}\text { Limbah } \\
(\mathrm{ml})\end{array}$} & \multicolumn{4}{|c|}{ NPK Organik (g) } & \multirow[b]{2}{*}{ Rerata } \\
\hline & $\mathrm{N}_{0}(0)$ & $\mathrm{N}_{1}(5)$ & $\mathrm{N}_{2}(10)$ & $\mathrm{N}_{3}(15)$ & \\
\hline $\mathrm{L}_{0}(0)$ & 69,33 & 68,00 & 67,00 & 65,00 & $67,33 \mathrm{~b}$ \\
\hline $\mathrm{L}_{1}(100)$ & 68,00 & 67,67 & 67,33 & 64,33 & $66,83 \mathrm{~b}$ \\
\hline $\mathrm{L}_{2}(200)$ & 66,67 & 67,33 & 65,00 & 63,33 & $65,58 \mathrm{ab}$ \\
\hline $\mathrm{L}_{3}(300)$ & 65,00 & 64,33 & 63,67 & 62,67 & $63,92 \mathrm{a}$ \\
\hline Rerata & $67,25 \mathrm{~b}$ & $66,83 \mathrm{~b}$ & $65,75 \mathrm{ab}$ & $63,83 \mathrm{a}$ & \\
\hline
\end{tabular}

Angka-angka pada baris dan kolom yang diikuti huruf kecil yang sama menunjukkan tidak berbeda nyata menurut uji lanjut Beda Nyata Jujur pada taraf $5 \%$

Umur panen pada tanaman timun suri tidak terlepas dari kecukupan unsur hara dan pengaruh lingkungan yang diperoleh oleh tanaman.Pamin et al.,(1996) menyatakan bahwa limbah cair yang dihasilkan oleh PKS dapat dimanfaatkan sebagai pupuk mengingat kandungan hara yang terkandung di dalamnya dapat digunakan oleh tanaman sebagai sumber hara. Limbah cair mengandung unsur nitrogen, fosfor, kalium, magnesium dan kalium.

Sementara itu, Yulia (2007) juga menyatakan bahwa pematangan buah mengacu kepada tahap akhir dari pengembangan bunga menjadi buah yang muncul dari efek pemenuhan hara, air dan kecepatan inisiasi bunga tanaman tersebut. Umur panen tidak 
lepas dari pengaruh inisiasi bunga dan daya adaptasi tanaman terhadap lingkungan, cahaya matahari, nutrisi, penyerapan karbondioksida yang berperan untuk pembungaan dan pematangan buah.

Kandungan fosfor yang terdapat didalam limbah cair pabrik kelapa sawit mampu mempengaruhi produksi buah yang dihasilkan, fosfor berperan dalam pemecahan karbohidrat untuk energi, penyimpanan dan peredarannya ke seluruh tanaman dalam bentuk ADP dan ATP. (Leiwakabessy dan Sutandi, 2004). Fosfor diserap dalam bentuk ion hidrogen fosfat $\mathrm{H}_{2} \mathrm{PO}_{4}$.

Pada Tabel 3, secara utama pemberian pupuk NPK organik berpengaruh nyata terhadap umur panen tanaman timun suri, dimana perlakuan terbaik terdapat pada $\left(\mathrm{N}_{3}\right)$ yaitu, 63,83 hari setelah tanam, tidak berbeda nyata dengan $\left(\mathrm{N}_{2}\right)$ yaitu, 65,75 hari setelah tanam. Akan tetapi berbedanya dengan $\left(\mathrm{N}_{1}\right)$ yaitu, 66,83 hari setelah tanam, dan umur panen terlama terdapat pada tanpa pemberian pupuk NPK organik $\left(\mathrm{N}_{0}\right)$ yaitu, 67,25 hari setelah tanam.

Umur panen pada suatu jenis tanaman sangat berkaitan dengan proses pembungaan. Semakin cepat umur berbunga, maka umur panen juga akan semakin cepat. Hal ini desebabkan proses pematangan buah lebih efektif dengan rentang waktu yang sama dalam pematangan buah dibandingkan dengan yang berbunga lebih lama (Dwidjoseputro, 2002).

Umur panen yang dicapai pada penelitian ini, telah sesuai dengan deskripsi tanaman timun suri. sedangkan hasil penelitan sebelumnya yang dilakukan oleh Syarif (2017) menyatakan bahwa umur panen paling cepat mencapai rerata 67,17 hari setelah tanam. Apabila dibandingkan umur panen pada Tabel 3 , umur panen mampu lebih cepat hingga mencapai selisih 4 hari setelah tanam. Perbedaan umur panen kemungkinan disebabkan oleh kebutuhan unsur hara yang terpenuhi serta lingkungan yang baik untuk pertumbuhan tanaman timun suri. Jumin (2002) menyatakan bahwa pada prinsipnya yang menyebabkan perbedaan masuknya umur panen adalah faktor genetik dan lingkungan. Salah satu faktor lingkungan adalah ketersediaan unsur hara dan cuaca.

Mukri (2009)menyatakan N, P, dan K berperan aktif dalam menentukan pembentukan buah. Mardawilis (2007), defisiensi unsur hara akan menurunkan produktifitas tanaman dan ditandai dengan rendahnya hasil produksi pada tanaman tersebut. Hasil suatu tanaman dibatasi oleh kekahatan unsur hara sehingga asupan hara, sistem imunitas dan transportasi dalam tubuh tanaman terganggu yang menyebabkan keberhasilan polinasi dan rasio pembentukan bunga betina lebih rendah dari bunga jantan sehingga jumblah buah tanaman yang dihasilkan menjadi lebih rendah.

\section{Jumlah Buah per Tanaman (Buah)}

Berdasarkan data pada tabel 3 menunjukan bahwa secara utama pemberian limbah cair pabrik kelapa sawit memberikan pengaruh yang nyata terhadap parameter jumlah buah pertanaman timun suri dimana jumlah buah pertanaman terbanyak terdapat pada pemberian limbah cair pabrik kelapa sawit 300 $\mathrm{ml}\left(\mathrm{L}_{3}\right)$ yaitu 4,08 buah yang berbeda nyata dengan perlakuan $\mathrm{L}_{2}, \mathrm{~L}_{1}$ dan $\mathrm{L}_{0}$.

Tabel 3. Rerata jumlah buah pertanaman timun suri perlakuan limbah cair pabrik kelapa sawit dan NPK organik (buah).

\begin{tabular}{cccccc}
\hline \multirow{2}{*}{$\begin{array}{c}\text { Limbah } \\
(\mathrm{ml})\end{array}$} & $\mathrm{N}_{0}(0)$ & $\mathrm{N}_{1}(5)$ & $\mathrm{N}_{2}(10)$ & \multirow{2}{*}{ Rerata } \\
\hline $\mathrm{L}_{0}(0)$ & 2,67 & 3,00 & 3,00 & 3,33 & $3,00 \mathrm{~b}$ \\
$\mathrm{~L}_{1}(100)$ & 3,00 & 3,00 & 3,33 & 3,67 & $3,25 \mathrm{~b}$ \\
$\mathrm{~L}_{2}(200)$ & 3,00 & 3,33 & 3,67 & 4,00 & $3,50 \mathrm{~b}$ \\
$\mathrm{~L}_{3}(300)$ & 3,67 & 4,00 & 4,00 & 4,67 & $4,08 \mathrm{a}$ \\
\hline \multicolumn{1}{c}{ Rerata } & $3,08 \mathrm{~b}$ & $3,33 \mathrm{~b}$ & $3,50 \mathrm{ab}$ & $3,92 \mathrm{a}$ & \\
\hline & & $\mathrm{KK}$ & $=13,84 \%$ & BNJL\&N $=$ & 0,53 \\
\hline
\end{tabular}

Angka-angka pada baris dan kolom yang diikuti huruf kecil yang sama menunjukkan tidak berbeda nyata menurut uji lanjut Beda Nyata Jujur pada taraf $5 \%$ 
Jumlah buah pertanaman yang dihasilkan dari penelitian ini terbilang tidak terlalu tinggi, apabila merujuk pada penelitian sebelumnya yang dilakukan Syarif (2017)mengenai dosis Bio organik plus dan pupuk Urea terhadap pertumbuhan dan produksi timun suri, dimana jumlah buah pertanaman yang terbanyak mencapai 7,83 buah pertanaman. perbedaan jumlah buah pertanaman pada tabel 3 lebih sedikit dibandingkan pada penelitian yang dilakukan Syarif, hal ini disebabkan karena bakal buah dan buah pada timun suri tidak bertumbuh dengan baik, beberapa buah timun suri mengalami kebusukan. Busuk buah yang menyerang timun suri diduga disebabkan oleh hama dan penyakit.

Batang timun suri bersifat menjalar panjang, daun yang lebar dan rimbun, sehingga tingkat kelembaban yang tinggi apabila mendapat suplai air yang cukup. Pada dasarnya tingkat kelembaban yang tinggi dapat memicu pertumbuhan patogen, jamur atau cendawan dan bakteri sehingga dapat menyebabkan penyakit pada tanaman seperti penyakit busuk buah. Hal ini sesuai dengan pernyataan Sherf dan Macnab (1986) menjelaskan bahwa suhu optimum yang dibutuhkan oleh patoken penyebab busuk buah adalah $21-30{ }^{\circ} \mathrm{C}$ dengan kelembaban yang sangat tinggi mendakati 100 $\%$ sedangkan pada musim kemarau tingkat kelembaban dilahan sangat rendah sehingga tidak mungkin patogen berkembang dengan cepat.

Selain dari faktor lingkungan kebutuhan unsur hara yang terpenuhi akan sangat berpengaruh bagi pertumbuhan serta produksi tanaman. Apabila ditinjau berdasarkan kebutuhan unsur hara nya, bisa dikatakan kebutuhan unsur hara pada timun suri telah terpenuhi, pernyataan ini sesuai apabila melihat kepada parameter umur berbunga dan umur panen timun suri yang masih sesuai dengan deskripsi timun suri, pernyataan Lingga (2002) juga menegaskan bahwa $\mathrm{N}, \mathrm{P}$ dan $\mathrm{K}$ merupakan unsur hara makro yang secara umum dibutuhkan oleh tanaman, dan dapat memberikan keseimbangan hara yang yang lebih baik untuk pertumbuhan dan produksi tanaman. Limbah cair yang berasal dari dari pabrik kelapa sawit memiliki kandungan bahan organik yang tinggi dan mengandung unsur hara makro seperti nitrogen $(\mathrm{N})$, posfor $(\mathrm{P})$ dan kalium (K) (Widhiastuti dan Donowati,2008).

Menurut Pambudi (2004), limbah kelapa sawit terdiri dari limbah padat dan limbah cair, limbah cair kelapa sawit mengandung unsur hara yang tinggi seperti $\mathrm{N}, \mathrm{P}, \mathrm{K}, \mathrm{Mg}$, dan $\mathrm{Ca}$ sehingga limbah cair tersebut berpeluang untuk digunakan sebagai sumber hara bagi tanaman, disamping berperan dalam memberikan kelembaban tanah, juga berperan dalam memperbaiki sifat fisik, kimia, dan biologis tanah. Sehingga limbah cair tersebut berpeluang untuk digunakan sebagai sumber hara bagi tanaman yang dapat dimanfaatkan secara maksimal sebagai pupuk organik alternatif.

Berdasarkan Tabel 3, secara utama pemberian pupuk NPK organik berpengaruh nyata terhadap jumlah buah pertanaman timun suri, dimana perlakuan terbaik terdapat pada $\left(\mathrm{N}_{3}\right)$ yaitu, 3,92 buah pertanaman, tidak berbeda nyata dengan $\left(\mathrm{N}_{2}\right)$ yaitu, 3,50 buahpertanaman. Akan tetapi berbedanya dengan $\left(\mathrm{N}_{1}\right)$ yaitu, 3,33 buahpertanaman, dan umur panen terlama terdapat pada tanpa pemberian pupuk NPK Organik $\left(\mathrm{N}_{0}\right)$ yaitu, 3,08 buahpertanaman.

Unsur hara seperti $\mathrm{N}$, $\mathrm{P}$, dan $\mathrm{K}$ juga berperan aktif dalam menentukan pembentukan buah. Hal ini berdasarkan fungsi unsur hara $\mathrm{P}$ dan $\mathrm{K}$ lebih berfungsi dalammempengaruhi pembentukan karbohidrat dan protein, translokasi dan transformasi, stimulus bagi enzim-enzim tertentu yang dapat memacu pembentukan buah dan biji (Agustina, 2004). Difisiensi unsur hara dapat menyebabkan putik yang terbentuk tidak mampu bertahan hingga masa panen. Artinya, kemungkinan buah rusak, cacat, terserang hama dan penyakit, bentuk buah tidak normal dan gugur sebelum waktunya akan tinggi yang dapat menurunkan jumlah buah yang dihasilkan tanaman (Prihmantoro, 2005).

\section{Berat Buah per Buah $(\mathrm{Kg})$}

Data pada tabel 4 terlihat bahwa secara interaksi pemberian limbah cair pabrik kelapa sawit dan NPK organik berpengaruh nyata terhadap berat buah perbuah tanaman timun suri. Berat buah perbuah tanaman timun suri terbaik oleh kombinasi pelakuan limbah cair pabrik kelapa sawit $300 \mathrm{ml} /$ tanaman yang 
dikombinasikan dengan pupuk NPK Organik 15 g/tanaman $\left(\mathrm{L}_{3} \mathrm{~N}_{3}\right)$ dengan berat buah per buah seberat $2,6 \mathrm{~kg}$, yang tidak berbeda nyata dengan perlakuan $\mathrm{L}_{1} \mathrm{~N}_{3}$ dan $\mathrm{L}_{2} \mathrm{~N}_{3}$ namun berbeda nyata dengan perlakuan lainnya. Sementara itu, berat buah per buah tanaman timun suri terendah terdapat pada perlakuan tanpa limbah cair pabrik kelapa sawit dan pupuk NPK organik $\left(\mathrm{L}_{0} \mathrm{~N}_{0}\right)$ yaitu, $1,0 \mathrm{~kg}$.

Tabel 4. Rerata berat buah per buah tanaman timun suri perlakuan limbah cair pabrik kelapa sawit dan NPK organik $(\mathrm{kg})$.

\begin{tabular}{|c|c|c|c|c|c|}
\hline \multirow{2}{*}{$\begin{array}{c}\text { Limbah } \\
(\mathrm{ml})\end{array}$} & \multicolumn{4}{|c|}{ NPK Organik (g) } & \multirow{2}{*}{ Rerata } \\
\hline & $\mathrm{N}_{0}(0)$ & $\mathrm{N}_{1}(5)$ & $\mathrm{N}_{2}(10)$ & $\mathrm{N}_{3}(15)$ & \\
\hline $\mathrm{L}_{0}(0)$ & $1,0 \mathrm{f}$ & $1,5 \mathrm{e}$ & $1,9 \mathrm{~cd}$ & $1,9 \mathrm{~cd}$ & $1,6 \mathrm{c}$ \\
\hline $\mathrm{L}_{1}(100)$ & $1,6 \mathrm{de}$ & $1,8 \mathrm{cde}$ & $1,9 \mathrm{~cd}$ & $2,3 \mathrm{ab}$ & $1,9 \mathrm{~b}$ \\
\hline $\mathrm{L}_{2}(200)$ & $1,8 \mathrm{cde}$ & $1,9 \mathrm{~cd}$ & $2,1 \mathrm{bc}$ & $2,3 \mathrm{ab}$ & $2,0 \mathrm{~b}$ \\
\hline $\mathrm{L}_{3}(300)$ & $1,9 \mathrm{~cd}$ & $2,0 \mathrm{bc}$ & $2,1 \mathrm{bc}$ & $2,6 \mathrm{a}$ & $2,2 \mathrm{a}$ \\
\hline \multirow[t]{2}{*}{ Rerata } & $1,6 \mathrm{~d}$ & $1,8 \mathrm{c}$ & $2,0 \mathrm{~b}$ & $2,3 \mathrm{a}$ & \\
\hline & $\mathrm{Kl}$ & $4,57 \%$ & BNJL\& & BNJLN = & \\
\hline
\end{tabular}

Angka-angka pada baris dan kolom yang diikuti huruf kecil yang sama menunjukkan tidak berbeda nyata menurut uji lanjut Beda Nyata Jujur pada taraf $5 \%$

Berat buah per buah tanaman timun suri yang dihasilkan telah mencapai bobot ratarata pada deskripsi tanaman timun suri, pada deskripsi berkisar antara 2,0-2,5 kg. Terbukti pada perlakuan $\mathrm{L}_{3} \mathrm{~N}_{3}$ berat buah per buah mencapai 2,6kg. Disamping itu berdasarkan penelitian sebelumnya yang dilakukan Fadli (2013) mampu menghasilkan berat buah per buah terbaik yaitu $1,36 \mathrm{~kg}$.

Sedangkan pada penelitian Syarif (2017) mampu menghasilkan berat buah per buah terbaik yaitu $1,40 \mathrm{~kg}$. Berat buah per buah pada penelitian sebelumnya masih berada dibawah berat buah per buah pada perlakuan $\mathrm{L}_{3} \mathrm{~N}_{3}$. Berat buah per tanaman berkaitan erat dengan jumlah buah per tanaman, Namun apabila melihat pada parameter jumlah buah pertanaman pada penelitian syarif, memperoleh jumlah buah per tanaman yang lebih tinggi. Hal ini diduga pada perlakuan $\mathrm{L}_{3} \mathrm{~N}_{3}$. telah terpenuhinya unsur hara pada tanaman timun suri, selain ituperbedaan jenis varietas timun suri yang digunakan pada penelitian syarif.

Menurut Wijoyo (2012).Berdasarkan jenisnya, Jenis timun dibagi menjadi dua golongan, yaitu timun yang pada buahnya terdapat bintil-bintil terutama bagian pangkalnya dan timun yang buahnya halus (tidak berbintil). Adapun penjelasannya adalah sebagai berikut : (1). Timun yang buahnya berbintil, dibedakan tiga macam: a. Timun biasa, timun biasa ditandai dengan penampilan kulit buah yang tipis, lunak dan pada saat buah muda berwarna hijau keputih-putihan, tetapi setelah tua berwarna cokelat. b. Timun watang, timun watang memiliki ciri-ciri kulit buah tebal, agak keras, buah muda berwarna hijau keputihputihan dan setelah tua berwarna kuning tua, dan c. Timun wuku, timun wuku memiliki ciriciri kulit buah agak tebal dan warna buah mudanya agak cokelat. (2) Timun yang buahnya halus, golongan timun yang buahnya halus tidak berbintil ada dua jenis, yaitu: a. Timun krai, timun krai buahnya besar dan memiliki ciri citarasa seperti timun biasa, b. Timun suri atau timun puan,

memiliki ciri-ciri ukuran buahnya besar hampir 10 kali besar timun biasa, bentuknya lonjong, rasanya manis renyah, dan umumnya dipanen saat buah tua/masak.

Pada penelitian syarif (2017) juga menyebutkan bahwa pada saat melaksanakan penelitian telah terjadi perubahan cuaca yang ekstrim, sehingga berdampak pada umur panen serta pertumbuhan penelitian timun suri. Sebagai mana yang disebutkan syarif Berdasarkan pendapat Maspray (2015), maka diketahui apabila terjadi cuaca yang tidak menetu (ekstrim) akan menyebabkan berbagai macam proses pertumbuhan dan perkembangan tanaman terganggu.

Maspray, (2015) menyatakan pengaruh langsung cuaca terutama radiasi penyinaran dan suhu terhadap fotosintesis, respirasi, transpirasi dan proses -proses metabolisme didalam sel organ tanaman sangat besar. Fotosintesis hanya berlangsung siang hari. Adapun intensitas respirasi daun sepenuhnya dipengaruhi oleh 
suhu udara dan berlangsung secara terusmenerus sepanjang umur tanaman. Apabila pengaruh suhu terhadap tanaman terutama pada proses fisiologi tanaman seperti: bukaan stomata, laju transpirasi, laju penyerapan nutrisi dan air, fotosintesis dan respirasi peningkatan suhu sampai titik optimum akan diikuti oleh proses diatas. Jika melewati titik optimum maka proses tersebut mulai terhambat baik secara fisik maupun kimia, dan menurunnya aktivitas enzim. Semenntara itu, curah hujan mempengaruhi tanaman melalui peroses ketersediaan air pada pori-pori tanah yang menguap. Jika curah hujan tinggi maka cadangan air yang ada dipermukaan tanah (pori-pori tanah) lebih besar dibandingan dengan penguapan air akibat proses evaporasi yang terjadi.

Pembentukan dan pembesaran buah timun suri yang maksimal diduga peran limbah cair pabrik kelapa sawit dan NPK organik mampu memperbaiki sifat fisik tanah seperti agregat, drainase, dan aerase, permaebilitas, pori-pori makro dan mikro. Rifandi (2010) menjelaskan bahwa pupuk organik dapat memperbaiki sifat kimia tanah seperti meningkatkan ketersediaan hara, menetralisir kemasaman dan menekan daya toksid $\mathrm{Al}$ dan $\mathrm{Fe}$ dalam tanah serta mampu memperbaiki sifat biologi tanah. Hal tersebut menyebabkan pertumbuhan akar menjadi maksimal, sehingga penyerapan air dan unsur hara berlangsung dengan baik. Keadaan ini menyebabkan unsur hara tersedia dengan optimum dan seimbang. Suatu tanaman akan tumbuh subur apabila segala unsur hara yang dibutuhkan cukup tersedia dan dalam bentuk yang sesuai untuk diserap tanaman dan menyebabkan proses fotosintesis menjadi maksimal sehingga pembentukan karbohidrat dan transformasi karbohidrat berlangsung sangat baik, akibat pengisian dan pembesaran buah maksimal.

Berdasarkan data pada tabel 5 menunjukan bahwa secara utama pemberian limbah cair pabrik kelapa sawit memberikan pengaruh yang nyata terhadap parameter berat buah per buah tanaman timun suri dimana berat buah per buah terbaik terdapat pada pemberian limbah cair pabrik kelapa sawit $300 \mathrm{ml}\left(\mathrm{L}_{3}\right)$ yaitu 2,2 $\mathrm{kg}$,yang berbeda nyata dengan perlakuan $\mathrm{L}_{2}, \mathrm{~L}_{1}$ dan $\mathrm{L}_{0}$.

Data pada Tabel 5, secara utama pemberian pupuk NPK organik berpengaruh nyata terhadap berat buah per tanaman timun suri, dimana perlakuan terbaik terdapat pada pemberian NPK organik $15 \mathrm{~g} /$ tanaman $\left(\mathrm{N}_{3}\right)$ yaitu, $2,3 \mathrm{~kg}$, yang berbedanyata dengan $\mathrm{N}_{2}, \mathrm{~N}_{1}$ dan $\mathrm{N}_{0}$.

Menurut Mukri (2009), unsur hara seperti $\mathrm{N}, \mathrm{P}$, dan $\mathrm{K}$ juga berperan aktif dalam menentukan pembentukan buah, Mardawilis (2007), defenisi unsur hara akan menurun produktifitas tanaman dan ditandai dengan rendahnya hasil produksi pada tanaman dan ditandai dengan rendahnya hasil produksi pada tanaman tersebut.

Selain itu, Salisbury dan Ross (1995) menyatakan bahwa keseimbangan jumlah buah dan kadar karbohidrat menjadi faktor pendukung meningkatnya kualitas hasil produksi. Karbohidrat merupakan senyawa yang tersusun atas glukosa dan fruktosa yang tersimpan sebagai cadangan makanan dalam bentuk karbohidrat yang memadat (pati). Keseimbangan antara jumlah karbohidrat dengan jumlah buah dapat mempertahankan hasil produksi terutama bobot buah per buah. Namun jumlah buah per buah yang tinggi dengan kerbohidrat rendah dapat menurunkan bobot buah per buah. Demikian halnya pada jumlah buah tinggi namun karbohidrat yang dihasilkan rendah, penurunan bobot buah perbuah akan terlihat jelas dari bentuk fisik buah yang kurang maksimal.

Sementara itu, Lingga dan Marsono (2007) berpendapat bahwa bobot buah juga di pengaruhi oleh banyaknya asimilasi yang dihasilkan melalui fotosintesis dan banyaknya jumlah buah yang dihasilkan tanaman tersebut. Hastuti (2000) menambahkan bahwa asupan unsur hara yang tepat akan meningkatkan proses pembentukan asimilasi, Akumulasi asupan asimilasi akan menentukan besar atau kecilnya daya simpan buah. Semakin tinggi akumulasi asupan asimilat yang diterima buah maka daya simpan bauh akan menjadi tinggi sehingga daging buah akan mengalami penebalan dan pemadatan. Akibatnya struktur buah tanaman menjadi keras dan padat sehingga bobot buah menjadi tinggi.

Tingginya berat buah per buah diduga kerana telah terpenuhinya kebutuhan unsur hara nitrogen yang dibutuhkan tanaman pada fase reproduktif yang cukup besar ketersediaan suplai unsur hara nitrogen yang sesuai kebutuhan tanaman timun suri pada periode 
reproduktif akan berpengaruh pada pembentukan buah yang optimal. Menurut Rinsema (1989) pada fase reproduktif pertumbuhan berat buah menuntut jumlah hara makro yang banyak seperti nitrogen, sehingga mobilitas dan translokasi dari bagian negotiatif ketempat perkembangan buah dan biji berjalan dengan baik dan sesuai dengan kebutuhan mobilitas dan translokasi tanaman. Perkembangan buah dan biji berjalan dengan baik akan berpengaruh langsung terhadap berat buah suatu tanaman.

Berdasarkan Tabel 5 diketahui adanya berat buah perbuah tanaman timun suri terendah pada perlakuan kontrol tanpa limbah cair pabrik kelapa sawit dan NPK organik $\left(\mathrm{L}_{0} \mathrm{~N}_{0}\right)$. Adapun berat buah per buah terendah tanaman timun suri yaitu $1,0 \mathrm{~kg}$, Hal ini diduga akibat terjadinya ketidak seimbangan unsur hara yang tentunya mempengaruhi ketersediaan jumlah kerbohidrat dan terganggunya proses pembentukan asimilasi.

Hal ini sesuai dengan pernyataan Amalia (2005) yang menyatakan bahwa kekurangan dan ketiadaan hara dapat menghambat fotosintesis tanaman yang kemudian akan berdampak besar terhadap proses asimilasi yang akan rendah, asimilasi yang rendah menyebabkan terjadinya ketidakseimbangan asupan asimilasi dengan jumlah buah yang terbentuk, akibatnya pembentukan dan perkembangan buah menjadi terhambat dan buah berukuran kecil. Selain itu, Agustina (2004) menyampaikan bahwa untuk meningkatkan bobot buah per buah perlu dilakukan pemupukan dengan dosis maksimum sehingga kerbohidrat yang dihasilkan juga sesuai dengan kebutuhan tanaman. Pemupukan dengan dosis yang minimum akan menyebabkan tanama kurang mampudalam meningkatkan serta mempertahankan bobot hinh

Dinamika Pertanian

\section{Berat Buah per Tanaman (kg)}

Data pada Tabel 6, diketahui bahwa secara interaksi pemberian limbah cair pabrik kelapa sawit dan NPK organik berpengaruh nyata terhadap berat buah per tanaman tanaman timun suri. Berat buah per tanaman tanaman timun suri terbaik dihasilkan oleh kombinasi perlakuan limbah cair pabrik kelapa sawit 300 ml/tanaman yang dikombinasikan dengan pupuk NPK Organik $15 \mathrm{~g} / \operatorname{tanaman}\left(\mathrm{L}_{3} \mathrm{~N}_{3}\right)$ dengan berat buah per tanaman seberat 12,1 kgyang berbeda nyata dengan kombinasi perlakuan yang lainnya. Sementara itu, berat buah per tanaman tanaman timun suri terendah terdapat pada perlakuan tanpa limbah cair pabrik kelapa sawit dan tanpa perlakuan NPK Organik $\left(\mathrm{L}_{0} \mathrm{~N}_{0}\right)$ yaitu $2,6 \mathrm{~kg}$.

Tabel 5. Rerata berat buah pertanaman timun suri perlakuan limbah cair pabrik kelapa sawit dan NPK organik $(\mathrm{kg})$.

\begin{tabular}{|c|c|c|c|c|c|}
\hline \multirow{2}{*}{$\begin{array}{c}\text { Limbah } \\
(\mathrm{ml})\end{array}$} & \multicolumn{4}{|c|}{ NPK Organik (g) } & \multirow{2}{*}{ Rerata } \\
\hline & $\mathrm{N}_{0}(0)$ & $N_{1}(5)$ & $\mathrm{N}_{2}(10)$ & $\mathrm{N}_{3}(15)$ & \\
\hline $\mathrm{L}_{0}(0)$ & $2,6 \mathrm{~h}$ & $4,5 \mathrm{~g}$ & $5,7 \mathrm{f}$ & $6,3 \mathrm{e}$ & $4,8 \mathrm{~d}$ \\
\hline $\mathrm{L}_{1}(100)$ & $4,8 \mathrm{~g}$ & $5,4 \mathrm{f}$ & $6,3 \mathrm{e}$ & $8,4 \mathrm{c}$ & $6,2 \mathrm{c}$ \\
\hline $\mathrm{L}_{2}(200)$ & $5,4 \mathrm{f}$ & $6,3 \mathrm{e}$ & $7,7 \mathrm{~d}$ & $9,2 \mathrm{~b}$ & $7,1 \mathrm{~b}$ \\
\hline $\mathrm{L}_{3}(300)$ & $6,8 \mathrm{e}$ & $8,0 \mathrm{~cd}$ & $8,4 \mathrm{c}$ & $12,1 \mathrm{a}$ & $8,8 \mathrm{a}$ \\
\hline Rerata & $4,9 \mathrm{~d}$ & $6,0 \mathrm{c}$ & $7,0 \mathrm{~b}$ & $9,0 \mathrm{a}$ & \\
\hline
\end{tabular}

$\mathrm{KK}=2,27 \% \quad$ BNJL\& $\mathrm{N}=0,2 \quad$ BNJLN $=0,5$

Angka-angka pada baris dan kolom yang diikuti huruf kecil yang sama menunjukkan tidak berbeda nyata menurut uji lanjut Beda Nyata Jujur pada taraf $5 \%$

Berat buah per tanaman timun suri yang dihasilkan telah mencapai berat buah per tanaman pada penelitian sebelumnya, dimana perlakuan $\left(\mathrm{L}_{3} \mathrm{~N}_{3}\right)$ berat buah per tanaman mencapai $12,1 \mathrm{~kg}$.Hasil penelitian sebelumnya yang dilakukan syarif (2017) tentang dosis Bio organik plus dan pupuk Urea terhadap pertumbuhan dan produksi timun suri mampu menghasilkan berat buah per tanaman terbaik yaitu $11,04 \mathrm{~kg}$. Selain itu, hasil penelitian Fadli (2013) tentang pengaruh berbagai jenis pupuk organik dan NPK organik terhadap timun suri mampu menghasilkan berat buah per tanaman terbaik yaitu $8,20 \mathrm{~kg}$. Berat buah per tanamn dan potensi produksi perhektar pada perlakuan 
$\left(\mathrm{L}_{3} \mathrm{~N}_{3}\right)$ lebih tinggi dari penelitian sebelumnya. Hal ini diduga karena adanya pengaruh komnbinasi perlakuan limbah cair pabrik kelapa sawit dan NPK organik telah mampu menyediakan energi yang kemudian digunakan tanaman untuk memproduksiu buah secara optimal. Selain itu, kombinasi perlakuan ini diduga mampu mensuplai unsur hara secara berkelanjutan dan sesuai dengan kebutuhan tanaman terhadap unsur hara serta mampu memperbaiki sifat fisik kimia dan biologi tanah secara maksimal sehingga fotosintesis berjalan dengan baik. Fotosintesis yang baik akan berpengaruh pada penyediaan jumlah kerbohidrat yang baik. Terpenuhinya kebutuhan unsur hara dan tersedianya karbohidrat sesuai kebutuhan tanaman timun suri akan mempengaruhi tanaman untuk mencapai berat pertanaman lebih maksimal dan meningkatkan potensi produksi tanaman.

Dwidjoseputro (2002) menyatakan bahwa hasil produksi tanaman sangat ... kan oleh

270

tıngkat pemenuhan unsur hara dan kemampuan tanaman dalam memaksimalkan kondisi lingkungan. Memaksimalkan kondisi lingkungan ialah termasuk didalamnya mengenai meningkatkan sistem imunitas tanaman terhadap perubhan kondisi lingkungan. Selain itu, Rosmmarkam dan yuwono (2011) menyampaikan bahwa unsur hara yang tersedia didalam media tanam yang mampu diserap tanaman dengan jumlah yang tepat dan seimbang mampu meningkatkan pembentukan buah, akibatnya jumlah buah lebih banyak dan berpengaruh pada berat buah, yaitu berat buah menjadi tinggi.

Hal ini sesuai dengan pendapat Wilkins (1990), bahwa jumlah dan berat tanaman sangat menetukan hasil produksi suatu tanaman kerna jumlah buah dengan berat buah yang tinggi mengindikasikan bahwa terpenuhinya kebutuhan unsur hara pada tanaman tersebut dengan baik. Selain itu, produksi tanaman yang diproleh dari hasil perkalian antara jumlah buah dan berat buah tinggi, secara optimis hasil produksi yang dihasilkan akan maksimal. Namun jumlah buah dan berat buah yang rendah akan menurunkan hasil produksi sehingga tidak optimal. Sementara hasil produksi dikatakan kurang maksimal kerena tidak terjadi keseimbangan antara jumlah dan berat buah yang dihasilkan sutau tanaman.

Berdasarkan data pada Tabel 5. Menunjukan bahwa secara utama pemberian limbah cair pabrik kelapa sawit memberikan pengaruh terhadap berat buah per tanaman terbaik terdapat pada pemberian limbah cair pabrik kelapa sawit $300 \mathrm{ml} /$ tanaman $\left(\mathrm{L}_{3}\right)$ yaitu $8,8 \mathrm{~kg}$ yangberbeda nyata dengan perlakuan lainnya.

Hasil berat buah per tanaman yang tinggi pada perlakuan $\left(\mathrm{L}_{3}\right)$ Diduga berkaitan erat dengan kandungan hara makro dan mikro esensial (N, P, K, S, Ca, Mg, B, Mo, Cu, Fe, $\mathrm{Mn}$, dan zat pengatur tumbuh). Limbah cair pabrik kelapa sawit merupakan termasuk jenis Pupuk organik cair selain dapat memperbaiki sifat fisik, kimia, dan biologis tanah, juga membantu meningkatkan produksi tanaman. Menurut Poerwowidodo (1992) mengumakakan bahwa pupuk organik cair mengandung unsur hara cukup lengkap yang berperan penting dalam setiap proses metabolisme tanaman, yaitu dalam sintesis asam amino dan protein dari ion-ion ammonium serta berperan dalam memelihara tekanan turgor dengan baik sehingga memungkinkan lancarnya prosesproses metabolisme dan menjamin kesinambungan pemanjangan sel serta meningkatkan bobot produksi tanaman.

Data pada Tabel 5 menunjukan bahwa secara utama pemberian NPK organik memberikan pengaruh terhadap parameter berat buat per tanman timun suri, dimana berat buah per tanaman terbaik terdapat pada pemberian NPK organik $15 \mathrm{~g} / \operatorname{tanaman}\left(\mathrm{N}_{3}\right)$ yaitu $8,8 \mathrm{~kg}$ yang berbeda nyata denganperlakuan lainnya.Tingginya hasil pada pengamatan berat buah per tanaman pada perlakuan $\left(\mathrm{N}_{3}\right)$ diduga karena nitrogen yang diserap tanaman telah mencukupi kebutuhan tanaman terhadap unsur hara nitrogen. Tercukupinya kebutuhan unsur hara nitrogen maka pertumbuhan tanaman akan optimal. Hal ini sesuai dengan pendapat Merigo (2006) bahwa untuk membentuk jarigan tanaman dibutuhkan unsur hara yang seimbang agar pertumbuhan tanaman berlangsung secara optimal, termasuk dalam bobot buah tanaman. Menurut Setyamidjaja (1986) menambahkan bahwa untuk mendapatkan hasil yang optimal, pupuk harus diberikan dalam jumlah yang mencukupi kebutuhan tanaman tidak berlebihan dan tidak berkurang, pemberian pupuk dalam 
jumlah yang tepat akan diperoleh hasil yang optimal.

Sementara itu, berdasarkan tabel 5 juga dapat dilihat berat buah per tanaman terendah yaitu pada perlakuan kontrol tanpa pemberian limbah cair kelapa sawit dan NPK organik. Berat buah per tanaman timun suri pada perlakuan kontrol hanya mencapai2,6 kg. Rendahnya berat buah per tanaman pada perlakuan $\mathrm{L}_{0} \mathrm{~N}_{0}$ diduga karena kurangnya suplai unsur hara terhadap tanaman. Suplai unsur hara yang rendah akan menyebabkan tidak maksimalnya proses pertumbuhan dan perkembangan tanaman timun suri. Sehingga tanaman tidak mampu menghasilkan produksi yang optimal. Nursanti (2008) mengemukakan bahwa asupan unsur hara yang rendah akan berakibat pada rendahnya asupan energi pada tanaman. Rendahnya asupan energi pada tanaman akan menyebabkan ketidak seimbangan asupan energi pada tanaman sehingga perkembangan buah yang berukuran kecil kemudian akan menyebabkan penurunan produksi yang signifikan. Selanjutnya disampikan Amalia (2005) bahwa unsur hara juga berpengaruh besar terhadap fotosintesis. Apabila fotosintesis terganggu maka hasil produksi suatu yanaman juga akan menurun.

\section{KESIMPULAN}

Berdasarkan hasil penelitian yang telah dilaksanakan, maka dapat diambil kesimpulan sebagai berikut :

1. Interaksi pemberian limbah cair pabrik kelapa sawit dan NPK Organik berpengaruh nyata terhadap berat buah per buah dan berat buah per tanaman tanaman timun suri. perlakuan terbaik adalah kombinasi limbah cair pabrik kelapa sawit $300 \mathrm{ml} /$ tanaman danpupuk NPK Otganik 15 g/tanaman (L3N3).

2. Pengaruh utama pemberian limbah cair pabrik kelapa sawit berpengaruh nyata terhadap umur berbunga, umur panen, jumlah buah per tanaman, berat buah per buah dan berat buah per tanaman tanaman timun suri. Perlakuan terbaik adalah dengan pemberian limbah cair pabrik kelapa sawit $300 \mathrm{ml} / \mathrm{tanaman}$ (L3).

3. Pengaruh utama pemberian pupuk NPK Organik berpengaruh nyata terhadap umur berbunga, umur panen, jumlah buah per tanaman, berat buah per buah, dan berat buah per tanaman tanaman timun suri. Perlakuan terbaik adalah dengan pemberian pupuk NPK organik $15 \mathrm{~g} /$ tanaman $(\mathrm{N} 3)$.

\section{DAFTAR PUSTAKA}

Agustina, L. 2004. Dasar Nutrisi Tanaman. Jakarta: PT Rineka Cipta. Lakitan dan Benyamin, 2007.

Amalia, Y. 2005. Penggunaan pupuk organik cair untuk mengurangi dosis penggunaan pupuk anorganik pada padi sawah (Oryza sativa L.). Skripsi Fakultas Pertanian Institut Pertanian Bogor. Bogor.

Badan Pusat Statistik. 2016. Indonesia Dalam Angka 2015. Indonesia. www.bps.go.id. Diakses pada 15 Febuari 2017.

Basir, M. P., Widowati dan Rusliani. 2003. Analisis kebijakan strategi dalam mendukung strategi pertanian organik. Jurnal Sains dan Teknologi Pertanian Fakultas Pertanian Universitas Gajah Mada.Yogyakarta. 22 (4) : 7-14.

Bertua, Irianto dan Ardiyaningsih. 2012. Pengaruh dosis pupuk kandang ayam terhadap pertumbuhan dan hasil timun (Cucumis sativus L.) pada tanah ultisol. Jurnal Agronomi Fakultas Pertanian Universitas Jambi. Jambi. 1 (4) ; 42-49.

Betty. 2007. Penanganan Limbah Industri. Kanisius. Yogyakarta.

Dwidjoseputro. 2002. Pengantar Fisiologi Tumbuhan. Gramedia Pustaka. Jakarta.

Fadli. 2013. Pengaruh pupuk kandang dan pupuk NPK terhadap pertumbuhan dan hasil tanaman timun suri (Cucumis sativusL.). Skripsi Program Studi Agroteknologi Fakultas Pertanian Universitas Islam Riau. Pekanbaru.

Hastuti, E. D. E. Prihastanti dan R. B. Hastusti. 2000. Fisiologi Tumbuhan II Universitas Diponegoro Press. Malang.

Ingsan. 2015. Uji pemberian herbafarm dan pupuk NPK organik terhadap pertumbuhan dan hasil tanaman timun suri (Cucunis sativus L). Skripsi Jurusan Agroteknologi Fakultas Pertanian Universitas Islam Riau. Pekanbaru.

Irawan, Y. 2015. Pengaruh pemberian limbah cair pabrik kelapa sawit dan pupuk SP-36 terhadap pertumbuhn dan produksi cabai merah. Skripsi Jurusan Agroteknologi 
Fakultas Pertanian Universitas Islam Riau. Pekanbaru.

Jumin, H. B. 2002. Agronomi. Raja Grafindo Persada. Jakarta.

Leiwakabessy, F.M. dan A. Sutandi. 2004. Pupuk dan Pemupukan. Departemen Ilmu Tanah. Fakultas Pertanian. Institut Pertanian Bogor. Bogor.

Lingga, P. 2002. Hidroponik Bercocok Tanam Tanpa Tanah. Penebar Swadaya. Jakarta.

Lingga, P. dan Marsono, 2007. Petunjuk Penggunaan Pupuk. Edisis Revisi Penebar Swadaya, Jakarta

Lubis, A.U dan Tobing, P.L. 2011. Potensi pemanfaatan limbah cair kelapa sawit. Buletin perkebunan. Medan.

Mardawilis. 2007. Pengaruh Pupuk Kandang Ayam dan Plant Catalys 2006 Terhadap Pertumbuhan dan Produksi Tanaman Pare (Momordica charantia L.) Jurnal Dinamika Pertanian (3) : 303-314.

Macnray. 2015. Pengaruh Iklim Terhadap

272 Tanaman . http://www.gerbangpertanian. com. Diakses pada 17 oktober 2017.

Mas'ud, A. 2013. Pertumbuhan dan Produksi Tanaman Timun (Cucumis sativus L.) pada Pemberian Pupuk Nitrogen. Jurnal Ilmu-ilmu Pertanian Universitas Negri Gorontalo. Gorontalo. 5(1): 1-19.

Merigo, A.J. 2006. Pengaruh pemanfaatan sludge kelapa sawit dan pupuk NPK terhadap pertumbuhan dan produksi jagung manis. Skripsi Program Studi Agroteknologi Faklutas Pertanian Universitas Islam Riau. Pekanbaru.

Mukri, D. 2004. Pemberian limbah kelapa sawit (sludge) dan NPK organik terhadap pertumbuhan dan produksi tanaman jagung manis (Zea mays Struth). Progam Studi Agroteknologi Fakultas Pertanian Universitas Islam Riau. Pekanbaru.

Nursanti. 2008. Pemanfaat Pupuk Bio-Organik Terhadap Beberapa Sifat Kimia Ultisol dan Populasi Mikroba Rhizosfer Serta Hasil Cabai (Capsicm Annum L.). Jurnal Agronomi Vol.12 No. 2. P 28-33.

Pamin, K., M.M. Siahaan dan P.L. Tobing. 1996. Pemanfaatan limbah cair PKS pada perkebunan kelapa sawit di Indonesia. Lokakarya nasional pemanfaatan limbah cair land aplication. Jakarta.

Poerwowidodo. 1992. Telaah Kesuburan Tanah. Angkasa Persada. Bandung.
Prihmantoro, H. 2005. Memupuk Tanaman sayuran. Penebar Swadaya. Jakarta.

Rifandi, A. 2010. Evaluasi penerapan sistem pertanian organik terhadap peningkatan produktivitas lahan dan tanaman. Jurnal Ilmu Pertanian Institut Pertanian Bogor. Bogor. 13 (9) : 23-27.

Rinsema, W.T. 1989. Pupuk dan Cara Pemupukan. Brahtama Karya Aksara. Jakarta.

Rismunandar. 1993. Hormon tanaman dan ternak. Penebar Swadaya. Jakarta.

Rosmarkam, A dan N. W. Yuwono. 2011. Ilmu kesuburan tanah. Kanisius Yogyakarta.

Setyamidjaja, D. 1986. Pupuk dan Pemupukan. Simplek Aksara. Jakarta.

Salisbury, F. B dan C. W. Ross. 1995. Fisiologi tumbuhan. Terjemahan Sumaryono Lukman. Plant Physiology edition. IPB press. Bandung.

Sherf, A.F. and A.A. Macnab. 1986. Vegetables diseases and their control. John Wiley and Sons, New York. Hal. 728

Sutanto, R. 2002. Penerapan pertanian Organik. Kanisius. Yogyakarta.

Syarif, M. 2017. dosis Bio organik plus dan pupuk Urea terhadap pertumbuhan dan produksi timun suri (Cucumis sativus L.). Skripsi Jurusan Agroteknologi Fakultas Pertanian Universitas Islam Riau. Pekanbaru.

Widhiastuti dan Donowati. 2008. Peranan beberapa zat pengatur tumbuh tanaman pada kultur invitro. Jurnal sains dan teknologi BPPT. Bandung. 3 (5) : 08-12.

Wijoyo, P. 2012. Budidaya Timun Yang Lebih Menguntungkan. Pustaka Agro Indonesia. Jakarta.

Wilkins, B. 1999. Fisiologi Tumbuhan. Bumi Aksara. Jakarta.

Yulia, D. N. 2007. Kajian fase fenologi dan fase pembuahan. Jurnal Biodeversitas Fakultas Pertanian Universitas Negri Surakarta. Solo. 8 (1) ; 11-21. 
